\title{
Text Writing Motivation of the Story of Nabi Bercukur in Nusantara Text Textological Study of Malay and Javanese Manuscripts
}

\author{
Nur Fauzan Ahmad ${ }^{1}$ Moh. Muzakka ${ }^{2}$ \\ $\left\{{ }^{1}\right.$ fazwan.268@gmail.com, ${ }^{2}$ muzakkamoh@yahoo.co.id $\}$ \\ Department of Indonesian Literature, Faculty of Humanities, Diponegoro University \\ Jl. Prof. Soedarto, Tembalang, Semarang, 50275, Indonesia
}

\begin{abstract}
The purpose of this study is to reveal the motivation for writing Nabi Bersyukur text in the Nusantara. It is because the popularity of the story text recorded in many copies of the text shows the readers' response to the text of the Nabi Bersyukur. This short article will examine the motivation of writing and welcoming readers of the Nabi Bercukur text in the Malay and Javanese texts. From the textological study of the Nabi Bersyukur stories found in Malay and Javanese texts as well as the motivation for writing and or copying the text, it can be concluded that Nabi Bersyukur became popular in the Nusantara because it was confirmed by the word of God contained in the Qur'an. Although the verse is actually related to the order of tahalul for the Hajj and Umrah, since it is quoted in the text of the story both in Malay and Javanese texts, it adds to the readers' confidence in the text Nabi Bercukur. There are different motivations in copying in both traditions. In the Malay text tradition, Nabi Bercukur is copied in accordance with the contents of the text which promises positive and threatening effects along with negative effects related to the story of the text and the manuscript that contains it. However, in the Javanese texts, the motivation for writing and copying the text is strengthened by the text of the prayer written at the end of the text, which is the prayer offered to increase the faith in Allah and the Messenger of Allah.
\end{abstract}

Keywords: Motivation; Prophet; shaving; effects; readers.

\section{Introduction}

The story of Nabi Bercukur was very famous and favored by the people of the Nusantara. This is proven by a large number of manuscripts scattered in various places both at home and abroad and documented in various regional languages as well. Dipodjojo said that besides being written in Malay, the story was also copied in various regional languages such as Sundanese, Acehnese, Makassarese, and Bugis [1].

The story of Nabi Bercukur contained in the Malay manuscript is quite numerous. In the National Library of the Republic of Indonesia (PNRI) Jakarta (formerly the Central Museum), there are 7 manuscripts (bundles) consisting of 9 texts with the title of the Story of Nabi Bercukur. In addition, the text is also stored in the Leiden Museum, London, and Gravenhage [2]

At the State Museum of the Special Province of Aceh (now NAD), there are at least two Nabi Bercukur manuscripts written in Acehnese with Jawi letters, namely the saga of Prophet Meucuko with the number MS. Inv. 1528 consisting of 112 pages and MS.Inv. 1595 which consists of 14 pages. 
In the treasures of Sundanese literature, according to information from Sundanese script researchers, Nabi Bercukur was documented in the Wawacan Nabi Paras text. As for the treasures of Bugis and Makassar literature, until now the author has not obtained clear information. Aside from being spread in the tradition of the five-language script, the story of Nabi Bercukur is also quite popular in Java, especially among the Pasisir people in North Central and East Java. The story is written in the form of poetry and prose. The story contained in the form of poetry is Singir Paras Nabi or Singir Paras Rasul; As for the story contained in the form of prose is Paras Lover Ingsun.

The manuscript documentation is quite a lot and the spread of extensive stories among the people of the Nusantara is not a mere factor of chance, but it does indicate a very high level of appreciation and meaning in the reading community. Therefore, to document and disseminate the text of stories that were popular in the past before the manuscript was destroyed by the times, comprehensive research is needed.

The research of the Nabi Bercukur in Nusantara texts has been carried out by several literary scholars and classical literary researchers, especially those who took philology specifications. However, research on the story is still partial, because researchers only take texts that develop in a particular nation and only focus their studies on certain aspects without conducting intertext comparisons and intertext studies of a number of existing texts. As a result, the efforts to reconstruct the spread of a fairly extensive story lead to the study of the history of the text has not yet materialized. Therefore, philology and textological research on the text of the Nabi Bercukur that is widespread in the Nusantara and abroad must be done immediately. Given the limitations of time and research funding, in this study, the material object is only in Javanese and Malay texts.

Nabi Bercukur texts have been discussed by several literary students partially and simply. This can be seen in the thesis made by Roosiati [3] and Muzakka [4] to obtain their degree. Roosiati [2] examined the stories of the Nabi Bercukur documented in Malay texts stored at the Jakarta National Museum (now PNRI). Based on the Prophet's Shaving Story, Roosiati only briefly talks about the structure of the story so that it does not discuss other prominent aspects of the story. Muzakka [4] conducted a study of Nabi Bercukur based on Javanese poetry entitled Singir Paras Nabi. In reviewing the text, Muzakka specifically examines the intrinsic and extrinsic elements that build the story based on the strata norm theory of Roman Ingarden. Muzakka discovered the aesthetic value of the poem, namely in the form of cohesiveness and strength of the elements of the structure both concerning the elements of sound, diction, and meaning.

The latest research on the story of Nabi Bercukur was carried out by Rizqiyah [ by taking a text titled Paras Kekasih Ingsun (PKI) which was found in the Mangkang Kulon Village collection of a Kiai who claimed to have obtained it from Kanjeng Sunan Kalijaga. Rizqiyah edited and translated the PKI manuscript then compared the contents of the story with the printed text of the verse Paras Nabi.

From the extensive data, the authors conclude that the Nabi Bercukur text is very popular in the Nusantara because, in addition to the numerous exemplars, it is also documented in several regional languages. Therefore, in this paper, the author tries to trace the history of the development of the text, especially those documented in Javanese and Malay texts.

\section{Method}


This research is classified as library research because the material objects of this study are the stories of Nabi Bercukur texts which are spread in Nusantara texts, especially those written in Javanese, Malay, Acehnese and Sundanese languages. The perspective of the study departs from textological studies, which traces the history of the development of text based on the data in the text so that it can be known where the text came from and why the text developed.

In this regard, the method of collecting data in this study is library research, which collects primary and secondary data about the popularity of the Nabi Bercukur based on the texts scattered in various libraries, museums, as well as manuscript collectors and other written sources related to the object of the research [5].

Once collected, these data are analyzed carefully using a textological approach. In this textological analysis, the author will look at the original text quoted by several texts in copies of manuscripts, both in Malay and Javanese texts. In this study, two Malay texts from the PNRI Jakarta collection and two Javanese texts from the collection of the community will be used. The two Malay manuscripts from the PNRI collection are manuscripts with the ML code. 60 and ML. 409. The Javanese manuscript used is the Javanese text of the Bani Noech family collection located at Penanggulan Village, Pegandon Subdistrict, Kendal Regency entitled Syi'ir Paras Nabi (Singir Paras Nabi) and manuscript collection of a Kiai from Mangkang Kulon, Tugu District, Semarang City which by his daughter Lalilatur Rizkiyah was titled Paras Kekasih Ingsun. In addition to the two Javanese manuscripts, a printed text entitled Syair Paras Nabi was published by Ahmad bin Sa'dun bin Nubhan Waaulaadihi, Surabaya (without years). This textological analysis begins with describing the text, observing its history, and viewing its content. So, from this stage history of the distribution of texts, copying the background, and motivation of the copyist will be drawn into the text in various texts and/or the text of the study above.

The method for presenting the data is descriptive. The presentation of the data in question is in writing data reports presented all of which are based on a set of data obtained from primary sources found in the object of study.

\section{Results and Discussion}

\subsection{Textological Study of Malay Manuscripts}

The story of Nabi Bercukur in Malay society is very popular. This is proven by the many copies of the manuscript found. Such reasons depart from the philological research assumption which states that more and more copies of manuscripts from a text are found which means that there are more and more readers' responses [5]. Moreover, if it is found in various forms/types of literary works that are spread in various ethnic groups that have different languages and cultures, the more popular the text of the story.

In a field search conducted at the National Library of the Republic of Indonesia (PNRI), the author found six copies of the manuscript entitled Hikayat Nabi Bercukur. The six texts are recorded with code number ML. 60, ML. 365, ML. 405, ML. 406, ML. 408, and ML. 409. Given a large number of copies of the manuscript, the author chose the most complete and easy-to-read text, the manuscript with the ML code. 60 and ML. 409.

The text of Nabi Bercukur contained in ML. 60 is written on 48 pages, while in the ML code. 409 is written in 10 pages. Manuscript ML. 60 recounts the events of Nabi Bercukur from pages 1 to 48. The story begins when the Prophet Muhammad was in the Holy Mosque of Mecca after his prayer and tadarus of the Koran was visited by Angel Jibril sent by Allah to 
shave the Prophet. The incident occurred on the night of Monday, the 19th of Ramadan, the year is not explained. The Angel Jibril conveyed Allah's command to the Messenger of Allah so that he shaved the head of the Prophet's hair. Therefore, the commandment of Allah is more specifically mentioned in the chunks of the word of Allah "muhalliqiina ru'uusakum wa muqashshiriina la takhaafuun", the Messenger of Allah also agreed. The procession of shaving activities went smoothly, especially guarded by the angels from heaven, no one knew about this shaving Prophet. No Prophet's hair fell to earth even though it was a piece.

There are interesting things from the text in this manuscript that are interesting and at the same time binding the reader to read, hear, and trust the events of the shaved Prophet. In addition, it binds the reader to copy and have documented text in the manuscript. How come people who read, hear, and believe the story of Nabi Bercukur will get God's protection in the world and the hereafter. For people who save and have stories, they will also be given safety when traveling both on the sea and on land, safe from interference from enemies, wild animals, as well as interference from jinn and demons. On the contrary, for people who do not want to read and hear and do not believe it, they will be tortured and punished by Allah in the world and in the hereafter, and will even become infidels when they die. Likewise, people who do not have their stories and do not keep their manuscripts will often be disturbed by wild animals, enemies, jinn and demons.

The outline of the contents of the ML. 409 manuscript is not much different from the ML. 60 manuscript. The striking difference is that after beginning with reading the basmalah, the story begins with the story of Abu Bakr who narrates and tells the story of the Prophet shaving to the friends whose stories he obtained from the Prophet Muhammad. In narrating the matter of the Prophet shaving, in this text, Abu Bakr began with a quote from the word of Allah as found in ML. 60. The event begins after the Messenger of Allah prayed and read the Koran in the Grand Mosque then visited the Angel Jibril who wanted to shave the Prophet. Even though the setting of the story is the same in the Grand Mosque, the setting is slightly different, which at night, Monday, the 18th of Ramadan.

\subsection{Textological Study of Javanese Manuscripts}

The story of the Prophet shaving in Javanese society was quite well known. This is proven by the discovery of story texts in two forms of literature, namely prose, and poetry. In the form of prose, this text appears in the manuscript collection of a Kiai from Mangkang Kulon, whose daughter gave the title Paras Kekasih Ingsun (PKI). As for poetry, it appears in the manuscript owned by Hj. Rukiyah entitled Syi'ir Paras Nabi. In addition to the two manuscripts, the popularity of the Nabi Bercukur story was supported by the publication of poetry texts by publishers from Surabaya under the title Syair Paras Nabi .

In the Paras Kekasih Ingsun manuscript, written in 19 pages, it is stated that the Prophet's shaving event that occurred at the 19th Ramadhan witnessed by the four companions of the Prophet was certainly not mentioned as in the Nabi Bercukur, namely the evening prayer and tadarus in the Holy Mosque. In the manuscript, the basmalah reading is not found but immediately tell about the Prophet's shaving. In the beginning, it was mentioned that the number of the Prophet's hair was about three thousand and three hundred thirty-three even none had fallen to earth because of being guarded by angels. Even if there is someone who has a hair of the Prophet, then his sins will be forgiven by Allah.

Furthermore, in the text it is explained as contained in the Malay text, which is about the benefits of reading, hearing, possessing and caring for stories promised by Allah's forgiveness, glory, the salvation of life in the world and in the hereafter. On the contrary, if 
you do not believe it, do not appreciate it, let alone denounce the incident of the shave Prophet will be wretched in the world and the hereafter, even for those who harm him, then that person becomes infidel at his death.

Actually, if we examine it in-depth, the story of Nabi Bercukur presented in the PKI text only leads to a teaching that the reader must have faith in and believe in Allah and the Messenger of Allah. It is because in the end the text is directed at a prayer that must be offered to God about the oneness of God that must be believed with all his heart and the Prophet Muhammad as the messenger of Allah. Based on these data, it seems that there is an alignment of objectives in understanding the story of the shaved Prophet aimed at readers in Javanese prose so as to avoid polytheism.

In line with the PKI, the story text contained in Syi'ir Paras Nabi was a collection of the Bani Noech family and/or printed manuscript entitled Syair Paras Nabi which also contained benefits for readers, listeners, owners and lovers of the shaved text/text of the Prophet's story. They are promised to get good values in the world and the hereafter. However, on the contrary, if they deny, it is threatened with punishment and torture. If we look at this story, it is only an illustration and an introduction that leads to the prayer at the end of the text, which is a prayer containing some of the names of Allah in the asma'ul husna. Such conditions as well as being a response to Malay texts that are considered copyists are not correct so that in the text the transformation follows the copyist ideology.

If we look at the text data, in the $P K I$, there is no mention of the name of the author and or copyist, the time of copying, and the place of copy, but if it is related to the contents of the text, the $P K I$ text is a transformation text from Malay texts, because the writer or copyist transforms the text as well as change it according to its ideology.

Unlike the PKI, in the text of Syi'ir Paras Nabi and Syair Paras Nabi which were printed at the beginning of the twentieth century information was found on the writing year. In both texts it is stated that Syi'ir Paras Nabi and Syair Paras Nabi were finished written on Saturday Wage, 8 Shafar $1319 \mathrm{H}$ or if converted by the year of $\mathrm{AD}$ is the end of the IX century, or later when compared to Malay texts.

\subsection{The Motivation for Text Writing}

Based on the textological study, the process of spreading the text and the motivation of writing the text of the Nabi Bercukur in the Nusantara can be seen, especially those spread among ethnic Malays and Javanese. The popularity of story texts in ethnic Malays recorded in many copies of the manuscript shows the readers' response to the text. The reader's response to that is strongly related to the motivation of the copyist. Copyist motivation is closely related to the content of the text which offers a positive effect for copyists. The positive effects offered by the text of the story are very promising, given the ease and happiness of life in the world and the hereafter. It could be that copying motivation arises because of the negative effects in the text for those who don't believe it and harm it.

These two reasons are probably what caused Nabi Bercukur to be copied, read, stored, and treated. It is because people who do not understand the teachings of Islam can strongly believe in what is presented in the text. This is proven by the many copies of the manuscripts by people who are not used to copying the script.

The motivation to write the story of the Nabi Bercukur in Javanese texts is not solely because it is promised to have a positive effect or fear of negative effects as contained in prose and poetry texts. However, the writing or copying is based on a critical view because of the 
efforts of the multiplier to direct the reader to the prayer at the end of the text. This proves that the Nabi Bercukur text in the text of the PKI and Syi'ir Paras Nabi and Syair Paras Nabi is not a promising and threatening goal for the reader. However, the story that was presented with extraordinary was used as an introduction or illustration for the reader in order to increase the faith in Allah SWT and the Prophet Muhammad.

\section{Conclusion}

From the textological study of the Nabi Bercukur stories to Malay and Javanese texts and the motivation of the author and/or copyist of the text, it can be concluded that the Nabi Bercukur text became popular in the Nusantara because it was associated with the word of God in QS. Alfath: 27. Although the verse is actually related to the order of tahalul for Hajj and Umrah, because it is quoted in the text of the story both in Malay and Javanese texts, it adds to the reader's belief in the text of Nabi Bercukur.

Although the text of the Nabi Bercukur was very popular among ethnic Malays and Javanese, the motivation for copying and writing was different. In the Malay text tradition, the Nabi Bercukur text is copied in accordance with the contents of the text which promises positive and threatening effects along with negative effects related to the story text and the manuscript that contains it. However, in the Javanese texts, the motivation for writing and copying is directed at the prayer written at the end of the text, namely the prayer offered to increase the faith in Allah and the Messenger of Allah.

\section{References}

[1]. Dipodjojo, A. S. Kesusastraan Lama Indonesia pada Zaman Pengaruh Islam. Yogyakarta: Lukman. (1981)

[2]. Sutaarga, M. A. Katalogus Koleksi Naskah Melayu. Jakarta: Dirjen Kebudayaan. (1972)

[3]. Roosiati, M. 1983 "Hikayat Nabi Bercukur dalam Sebuah Pembicaraan". Bachelor Thesis Faculty of Letters, Diponegoro University. (1983)

[4]. Muzakka, M. "Analisis Struktur Singir paras Nabi". Bachelor Thesis Faculty of Letters, Diponegoro University. (1989)

[5]. Chamamah-Soeratno, S. "Penelitian Sastra dari Sisi Pembaca: Satu Pembicaraan Metodologi”. In Jabrohim (Ed.) Teori Penelitian Sastra. Yogyakarta: MPI IKIP Muhammadiyah. (1994)

[6]. Muzakka, M. Fungsi Singir bagi Masyarakat Santri. Kajian Sastra No. XX-XXI. (1999) 